\title{
A NEW NAME, AND NOTES ON EXTRA-FLORAL NECTARIES, IN LAGUNARIA (MALVACEAE, MALVOIDEAE)
}

\author{
L.A. CRAVEN ${ }^{1}$, C. MILLER ${ }^{2} \&$ R.G. WHITE ${ }^{2}$
}

\author{
SUMMARY
}

The Australian taxon Lagunaria patersonius subsp. bracteata is raised to specific rank as L. queenslandica, based upon morphological and ecological dissimilarities between it and the autonymic taxon, L. patersonius subsp. patersonius. The latter taxon occurs on the southwest Pacific Ocean islands, Lord Howe and Norfolk Islands. Extra-floral nectaries are reported in Lagunaria, apparently for the first time, and contrasted with those occurring in species of Hibiscus sections Bombicella and Furcaria.

Key words: Malvaceae, Hibiscus, Lagunaria, extra-floral nectaries.

\section{INTRODUCTION}

The genus Lagunaria (DC.) Rchb. was established by Reichenbach (1828), based upon Hibiscus section Lagunaria DC. Bentham (1863) redefined the genus to comprise the single tree species, L. patersonius (Andrews) G. Don, up to that time known only from Norfolk Island in the southwest Pacific Ocean. Bentham also recorded the species from Queensland, Australia, and described a variety, L. patersonius var. bracteata Benth., to accommodate the Australian populations (Bentham, 1863).

The position of Lagunaria in the Malvaceae has been unclear. Bayer \& Kubitzki (2002: 237, 277) treated it as of uncertain position, noting that it was one of several genera that were intermediate between subfamilies Bombacoideae Burnett and Malvoideae Burnett. Phylogenetic analysis of chloroplast sequence data obtained from the $n d h F$ gene and the $r p l 16$ intron showed that, on these data, Lagunaria nested with Malvoideae and not with Bombacoideae (Pfeil et al., 2002). The genus, however, did not associate strongly with Hibisceae Rchb., as had been anticipated, but always formed a robust clade with the Australian genus Howittia F. Muell., a clade that was variously associated with other groupings of Malvoideae tribes and/or genera. Analysis of the nuclear $r p b 2$ gene (that encodes a subunit of RNA polymerase II) showed that Lagunaria contained two copies of the gene, as did Howittia, Hibiscus, Pavonia Cav. and Urena L. (Pfeil et al., 2004). As with the cpDNA data, Lagunaria and Howittia formed strongly supported clades but the two Lagunaria-Howittia rpb2 clades were sister to the Hibiscus-centred clade, these clades forming a well-supported clade that was sister to the remainder of the Malvoideae.

1) Australian National Herbarium, CPBR, CSIRO Plant Industry, G.P.O. Box 1600, Canberra, ACT 2601, Australia.

2) CSIRO Plant Industry, G.P.O. Box 1600, Canberra, ACT 2601, Australia. 


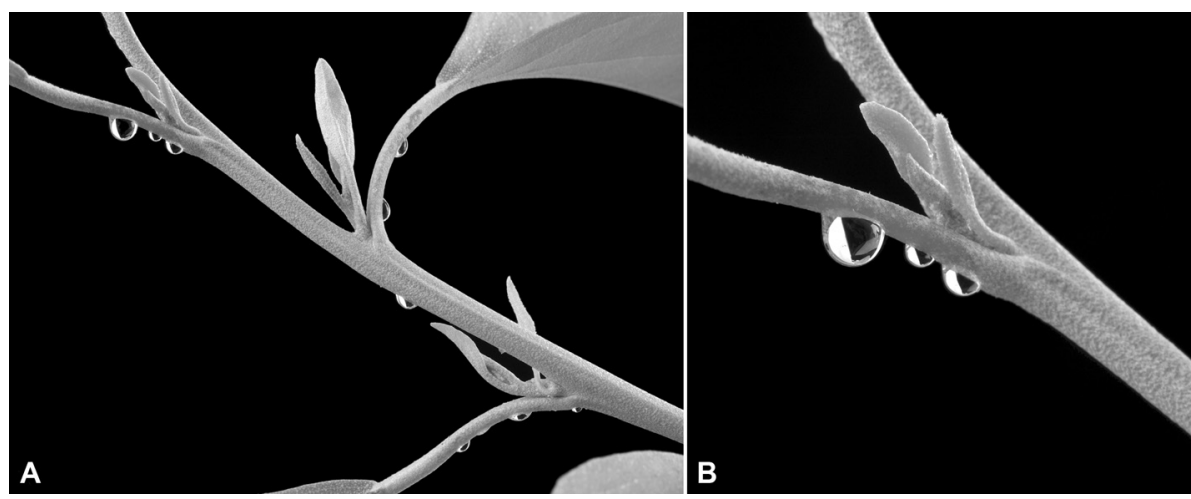

Fig. 1. A, B. Habit photographs showing droplets of nectar on the petioles of Lagunaria queenslandica Craven.

During the continuing studies of Australasian Malvoideae being undertaken in Canberra, the taxonomic status of the Australian populations of Lagunaria has been reconsidered. Observed differences between the island and Australian populations are discussed below; they are regarded as significant and worthy of higher rank than accorded by Green (1990), and the new species L. queenslandica Craven is established to accommodate the Australian representatives of the genus. Plants, derived from a population occurring in the Saltwater Creek region, c. $100 \mathrm{~km}$ west of Townsville, Queensland, were being cultivated in a Canberra greenhouse. Nectar was observed to be present on the petioles of youngish leaves (Fig. 1) of these plants but differentiated glands could not be seen. As extra-floral nectaries in Lagunaria apparently have not been recorded in the literature, the opportunity was taken to investigate the phenomenon further. The Lagunaria secretory tissues were compared with those of two species of Hibiscus, H. forsteri F.D. Wilson (sect. Furcaria DC.) and H. peralbus Fryxell (sect. Bombicella DC.), being cultivated in the same greenhouse, and these comparisons are discussed below.

\section{MATERIALS AND METHODS}

Plants of Hibiscus forsteri, H. peralbus and Lagunaria queenslandica were maintained as potted plants in a greenhouse at CSIRO, Canberra, with day and night temperatures maintained at 27 and $22{ }^{\circ} \mathrm{C}$, respectively. All plants are about six years old. The two Hibiscus species are shrubs and flower regularly but the Lagunaria, a tree in its natural habitat, has not flowered. Material of healthy growth that was actively secreting was collected for examination in the laboratory.

\section{Cryo-scanning electron microscopy}

Areas of midrib from the leaf base and petiole of young, mature leaves with petiolar secretions were selected for examination in a JEOL 6400 SEM (JEOLAustralasia, Sydney, Australia) fitted with an Oxford CT1500 Cryotrans system (Oxford Instruments, Sydney, Australia). Secretory regions and adjacent non-secreting areas were examined. 
The secretory areas were observed with exudate before, or without exudate after, washing with water then drying. Tissue pieces were mounted in carbon/graphite adhesive paste (ProSciTech, Australia) on flat copper stubs, then frozen in the pre-cooled (to $\pm-180{ }^{\circ} \mathrm{C}$ ) Oxford cryo-preparation chamber, sputter coated with gold and examined at $15 \mathrm{kV}$ (Craig \& Beaton, 1996). Digital images were captured using ImageSlave (OED, Sydney, Australia).

\section{Light microscopy}

Using leaves similar to those described above, thin slices of tissue were cut transversely from different parts of the petiole and from the midrib of the leaf base. The tissue samples were vacuum-infiltrated in $3 \%$ glutaraldehyde in $25 \mathrm{~mm}$ sodiumphosphate buffer, $\mathrm{pH} \mathrm{7.2,} \mathrm{for} 1$ minute and fixed for 3 hours at room temperature, then placed in fresh fixative overnight at $4{ }^{\circ} \mathrm{C}$. After washing in buffer, the samples were dehydrated through a graded ethanol series, infiltrated into LRWhite resin (London Resin Co., Berkshire, UK), and flat embedded at $60{ }^{\circ} \mathrm{C}$ under nitrogen gas. Sections $1 \mu \mathrm{m}$ thick were stained with aqueous Toluidine blue $\mathrm{O}(0.1 \% \mathrm{w} / \mathrm{v})$, examined in a Leica DMR microscope and images captured using a Leica DC500 digital camera.

\section{EXTRA-FLORAL NECTARIES}

\section{Hibiscus forsteri}

Leaves of this species have a well-defined, or structural, extra-floral nectary on the abaxial surface of the leaf midrib at the base of the leaf blade immediately distal to the top of the petiole (Fig. 2A, B). Under cryo-SEM, the slit in the midrib can be seen to secrete nectar (Fig. 2A). Cross sections of the nectary reveal a cluster of multicellular secretory trichomes, or glands, along the base and approximately $1 / 3$ of the way up each side of the deep slit (Fig. 2C, D). These are normally covered with a clear secretion in young mature leaves. Large, longitudinal, internal ducts oriented along the length of the midrib also contain secretory material, some of which is deeply stained by toluidine blue and thus appears different from the non-staining glandular secretions from the nectary.

\section{Hibiscus peralbus}

This species has no structural extra-floral nectary; instead, a region on the abaxial surface at the base of the leaf blade, immediately distal to the top of the petiole, produces a clear secretion under certain conditions (Fig. 2E). In comparison to adjacent, non-secretory tissue, this region is characterised by abundant stomata and smaller, less elongate and less regular epidermal cells. Sparse, multicellular, glandular trichomes are present on all regions of the petiole, but are somewhat more abundant in the secretory area (Fig. 2F, G). In cross section, the epidermal cells are columnar in shape, being radially, rather than longitudinally elongated (Fig. 2G). In adjacent, non-secreting parts of the petiole (Fig. 2H) or leaf midrib (Fig. 2G), few glands are seen, although the epidermal cells are somewhat columnar in the adjacent midrib (Fig. 2I).

\section{Lagunaria queenslandica}

The dense indumentum possessed by this species (Fig. 1) is composed of multicellular, peltate trichomes (Fig. 2J, K). There is no structural nectary, nor is there a recog- 


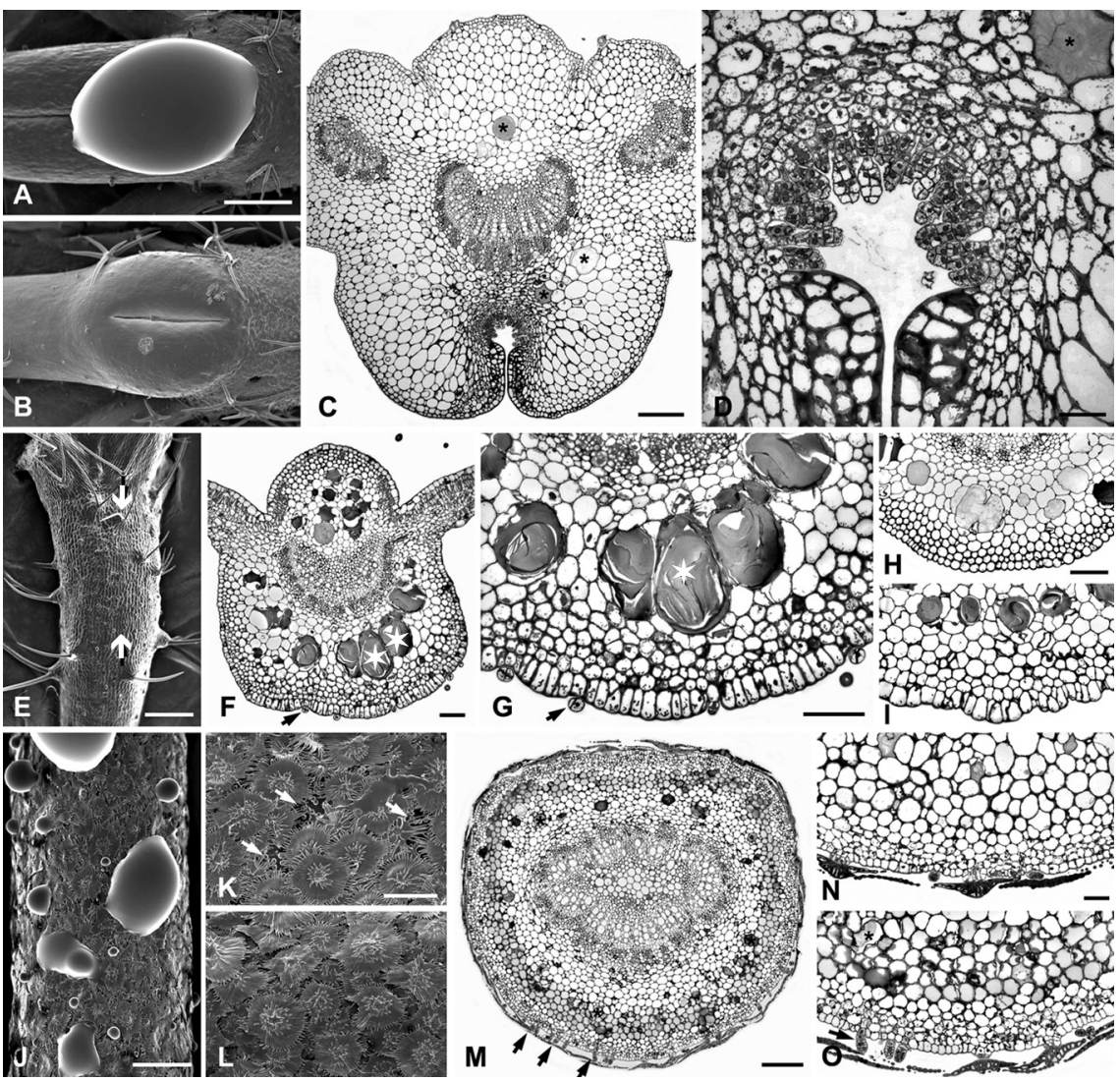

Fig. 2. Cryo-SEM images (A, B, E, J-L) and light micrographs from toluidine-blue stained resinembedded cross sections (C, D, F-I, M-O) of leaf midribs and petioles from Hibiscus forsteri F.D. Wilson (A-D), H. peralbus Fryxell (E-I) and Lagunaria queenslandica Craven (J-O). - A, B. Abaxial surface of $H$. forsteri leaves showing conspicuous nectary at the junction between petiole and leaf blade with (A) and without (B) secreted material. - C, D. Cross section of nectary region showing abundant multicellular trichomes concealed within the deep abaxial slit. Longitudinal ducts (indicated by asterisks) contain darkly-staining material. - E. Abaxial surface of H. peralbus leaf showing the 'pad' of nectary tissue (between arrows) at the distal end of the petiole just below the junction between petiole and leaf blade (with secreted material removed). - F, G. Cross section of nectary region showing sparse, multicellular trichomes (indicated by arrows) among columnar epidermal cells. Abundant longitudinal ducts (indicated by asterisks) contain darkly-staining material. $-\mathrm{H}$. The abaxial surface of the midrib above the nectary region, showing epidermal cells which are symmetrical in cross section. No glands are visible in this section. - I. Epidermal cells immediately below the nectary region are somewhat enlarged. - J, K. Abaxial surface of Lagunaria queenslandica petioles showing nectary region just below the junction between petiole and leaf blade with $(\mathrm{J})$ and without $(\mathrm{K})$ secreted material. Multicellular trichomes (indicated by arrows) can be detected between the abundant peltate hairs. - L In the adjacent, non-nectary region, only the peltate hairs are visible. $-\mathrm{M}, \mathrm{O}$. Cross section of nectary region showing abundant glandular trichomes (indicated by arrows) underneath the peltate hairs, which have elongated stalks. Longitudinal ducts (indicated by asterisks) contain darkly-staining material. $-\mathrm{N}$. The adjacent non-nectary region showing closely-appressed peltate hairs and few glandular trichomes. - Scale bars: in A for A \& B $=1 \mathrm{~mm} ; \mathrm{C}=250 \mu \mathrm{m}$; D and in $\mathrm{N}$ for $\mathrm{N} \& \mathrm{O}=50 \mu \mathrm{m} ; \mathrm{E}, \mathrm{J}=500 \mu \mathrm{m} ; \mathrm{F}-\mathrm{I}=100 \mu \mathrm{m} ; \mathrm{K}-\mathrm{M}=200 \mu \mathrm{m}$. 
nisable 'pad' of secretory tissue as in H. peralbus. Here, the non-structural nectary region is on the abaxial surface of the petiole (Fig. 2J), and is characterised by multicellular, glandular trichomes which, in cryoSEM, can be seen between the peltate hairs (Fig $2 \mathrm{~K})$. The peltate hairs are also more widely spaced and less tightly overlapping than in non-secretory regions (Fig. 2L). In cross section, many multicellular glandular trichomes can be seen beneath the peltate hairs in the nectary region, and these hairs are raised above the abaxial epidermis (Fig. 2M). The glandular trichomes are much less abundant in adjacent non-nectary regions, and the peltate hairs appear to be appressed closely to the epidermis (Fig. 2N, O). The petiole also contains many large, internal, longitudinal ducts which conduct densely staining material, much of which was secreted from the tissue during fixation.

\section{DISCUSSION OF EXTRA-FLORAL NECTARIES}

While the occurrence of extra-floral nectaries is easily established in the case of species such as those of Hibiscus sect. Furcaria and Urena australiensis Fryxell \& Craven, in which the nectaries are well differentiated, they are less easily observed in some other malvaceous species. In H. peralbus, and the related H. hirtus L., in the absence of droplets of nectar, the nectaries are not immediately evident as the associated tissues are not well differentiated. In the case of Lagunaria, there is no morphological differentiation, other than an increased density of glandular trichomes, that can be used as a reliable guide to the nectariferous surfaces. The secretory trichomes in the three species reported upon here are similar in structure to those discussed by Vogel (2000) in a review of floral nectaries in Malvaceae.

It is tempting to speculate that the observations reported here reflect an evolutionary progression with the unspecialised Lagunaria representing the primitive condition, the 'pads' of $H$. peralbus an intermediate condition, and the slit-like glands of Hibiscus sect. Furcaria and Urena representing advanced stages of development. Before any such conclusions can be drawn, however, it will be necessary to determine whether or not the other members of Malvoideae lacking glands or pads have similar extra-floral nectaries to those occurring in Lagunaria and H. peralbus. Greenhouse cultivation of the species to be investigated probably will be essential as it is expected that insects are effective at removing nectar produced in field and/or garden situations.

\section{MORPHOLOGY AND ECOLOGY}

Bentham (1863) distinguished the two varieties of L. patersonius on the basis of the Norfolk Island form being more "scaly-tomentose", having broader leaves that were much whiter abaxially, and having a caducous epicalyx. In his description of var. bracteata, he described the epicalyx (as "bracteoles") as being "3 to 5, very obtuse, united in a broad, shortly-lobed cup, usually persistent at the time of flowering" (Bentham, 1863). He further noted that he had been intending to recognise the Queensland form as a distinct species but that the epicalyx in the Norfolk form was sometimes present on very young buds, and occasionally was caducous in the Queensland materials he had available. 
The autonymic variety, L. patersonius var. patersonius, also occurs on Lord Howe Island, which is nearly $1000 \mathrm{~km}$ southwest of Norfolk Island. Green (1990) noted that the leaf indumentum could not be used to discriminate between the Queensland and island forms, but that the length of the style and its degree of protrusion from the flower were diagnostic. The style is longer, and hence more exserted, in the Queensland populations and Green considered that this, together with the separate ranges of the two forms, warranted their treatment at the rank of subspecies, which he effected (Green, 1990). The description of the genus and of L. patersonius subsp. patersonius given by Green (1994a) in a flora of Norfolk and Lord Howe Islands in 'Flora of Australia' (an inexplicable placement for a floristic account of oceanic islands!) is erroneous with respect to his interpretation of the epicalyx in the Norfolk and Lord Howe Islands populations. The epicalyx is described as being "reduced to a ridge surrounding base of calyx" (Green, 1994a). In the materials available in Canberra, there are several collections from the islands in which an epicalyx is present on very young buds; the epicalyx is caducous and the tissue upon which it had been inserted develops by the time of anthesis into a distinct ridge. A similar ridge exists in the Queensland populations, in which the epicalyx may be caducous or deciduous.

Green's conclusion that variation in leaf indumentum was insufficient to distinguish taxonomically between the Queensland and island populations (Green, 1990), is confirmed. The epicalyx features discussed by Bentham (1863) and Green (1990, 1994a) are unreliable and should not be weighted heavily as taxonomic discriminators. Our observations are that the epicalyx is caducous in the island populations and caducous or deciduous in the Queensland populations. In his floristic account, Green (1994a) describes the epicalyx in subsp. bracteata (Benth.) P.S. Green as being caducous; this is in contrast with his description "sometimes more or less persistent" in Green (1990). There is weak qualitative and quantitative variation between the Queensland and island populations in other aspects of the epicalyx. In the Queensland populations, the epicalyx is connate and 3-5-lobed, with an imperfectly connate condition being noted in Bean 2546 in which the 3-lobed epicalyx has a split to the base. In the island populations, the epicalyx usually consists of 2 free lobes, but Hoogland 8632 possesses a similar epicalyx to Bean 2546 , i.e. it is 3-lobed but imperfectly connate having a split right to the base.

The staminal column and petals provide data that can be used to demonstrate nonoverlapping differences between the two sets of populations, in contrast to the epicalyx features discussed above or the leaf differences that have been adequately discussed by Green (1990). The length of the petals, staminal column, and antheriferous portion of the column differs, generally being shorter, shorter and longer, respectively, in the island populations than in those from Queensland (Table 1). The ratio of the length of the antheriferous portion to the total staminal column length and the ratio of the length of the antheriferous portion to the petal length (Table 1) give non-overlapping values. The antheriferous portion: staminal column ratio is $0.39-0.55$ in the island populations and $0.18-0.24$ in the Queensland populations, and the antheriferous portion : petal ratio is $0.31-0.43$ and $0.17-0.25$, respectively.

The provenance of the cultivated genotype in southeast Australia conventionally is thought to be Norfolk Island. The cultivated New South Wales collection listed in 
Table 1. Floral measurements and indices of Lagunaria.

\begin{tabular}{llrrrr}
\hline & & & & & \\
& & &
\end{tabular}

Table 1 agrees with the island collections in its floral measurements and ratios and it seems that Norfolk Island could well be the origin for the cultivated genotype. Based on their respective ecologies (see below), the island genotypes could be expected to grow significantly better in the winter-wet parts of Australia than could the central Queensland populations, and the trees cultivated in temperate Australia certainly thrive.

The two sets of populations have different ecologies, and are subject to different climates. Norfolk Island was, in 1788, covered with a dense subtropical forest and has a subtropical oceanic climate with the wettest months being April to August (Green, 1994b). The tree flora of Lord Howe Island is mostly in rainforest or swamp forest communities and the island has a generally similar climate to Norfolk Island with rainfall generally occurring from March to October (Green, 1994b). The Queensland populations, on the other hand, occur in non-rainforest, riparian vegetation along small seasonal stream lines, often in the stream bed, or in deciduous monsoon forest. The Queensland populations occur in regions in which the rainfall generally occurs from November to April. Broadly speaking, the islands have a winter rainfall-biased climate whereas the Queensland populations occur in a summer rainfall environment with a pronounced dry season during the winter months.

In view of the morphological and ecological differences existing between the Queensland and island populations of Lagunaria, it is concluded that the taxonomic rank of species is warranted. Rather than maintaining the non-diagnostic and hence inappropriate epithet 'bracteata', the opportunity is taken to give the Queensland plant an epithet that is more readily associated with its geographic occurrence, and which serves to reinforce its distance from the oceanic islands upon which the other Lagunaria species occurs. 


\section{NOMENCLATURE}

As observed by Green (1990), the orthography accorded to the specific epithet has not been stable. The spellings patersonius, patersonia, patersoni and patersonii have all been employed by authors. Green (1990) adopted the form patersonia, apparently influenced by Sims (1804). However, the author who described the species, Andrews, appears to have deliberately adopted the orthography patersonius. In discussing the generic placement of the species, Andrews elected not to assign the species to the genus Lagunaea Schreb.: "so we have rather given our present subject, the name under which it is in general known" (Andrews, 1803), which presumably was Hibiscus patersonius. In keeping with the principle of priority, patersonius is retained here. Another matter pertaining to orthography requires comment, i.e. the gender of Lagunaria. The ICBN in Article 62.1 states that a "generic name retains the gender assigned by botanical tradition, irrespective of classical usage or the author's original usage" (Greuter et al., 2000). A survey of generic names in ING (Farr \& Zijlstra, 2006) that have the termination '-aria' indicates that such names have been consistently treated as feminine. The first species placed in Lagunaria, L. patersonius (Andrews) G. Don (as patersonii) and L. cuneiformis G. Don (Don, 1831), have as their specific epithets a noun and an adjectival form that might be masculine or feminine, respectively, and consequently do not give a clear intention as to the gender of Lagunaria. The epithet of the third species ascribed to the genus, L. lilacinus (Lindl.) Sweet (Sweet, 1839) was given the masculine form of its basionym, Hibiscus lilacinus Lindl. Bentham's orthography for his varietal epithet 'bracteata' (Bentham, 1863) suggests that he considered Lagunaria to be feminine. Initially, Green followed Bentham and used 'bracteata' (1990) but he later adopted without comment the masculine spelling 'bracteatus' (Green, 1994a). Botanical tradition is followed here and Lagunaria treated as feminine.

\section{Lagunaria queenslandica Craven, stat. \& nom. nov.}

Replaced name: Lagunaria patersoni var. bracteata Benth. (1863) 218. - Lagunaria patersonia subsp. bracteata (Benth.) P.S. Green (1990) 242. - Type (fide Green (1990) 242): Fitzalan s.n. (lecto K n.v.), Queensland, near Port Denison.

\section{ACKNOWLEDGEMENTS}

Dale Dixon and Garry Sankowsky are thanked for providing specimens of the Queensland Lagunaria, and Russell Cumming gave a précis of his observations of its ecology. Peter Bostock kindly reported upon label data for the holdings of the genus in BRI. Tony Orchard is thanked for discussing the orthography of the epithet 'patersonius' and the gender to be attributed to Lagunaria, and Hans Nooteboom is thanked for his input to the latter. Carl Davies took the photographs used in Fig. 1A and 1B. Anna Monro and Ed Cross are thanked for their comments on the manuscript.

\section{REFERENCES}

Andrews, H.C. 1803. Hibiscus patersonius. Bot. Repos. 4: t. 286.

Bayer, C. \& K. Kubitzki. 2002. Malvaceae. In: K. Kubitzki, The families and genera of vascular plants 5: 225-311. Springer, Berlin.

Bentham, G. 1863. Lagunaria. In: G. Bentham, Flora Australiensis 1: 218-219. 
Craig, S. \& C. Beaton. 1996. A simple cryo-SEM method for delicate plant tissues. J. Microscopy 182: $102-105$.

Don, G. 1831. Lagunaria. Gen. Hist. 1: 485.

Farr, E. \& G. Zijlstra. 2006. Index nominum genericorum. URL: http://ravenel.si.edu/botany/ing/ingForm.cfm (Accessed 16 February 2006).

Green, P.S. 1990. Lagunaria. Kew Bull. 45: 240-242.

Green, P.S. 1994a. Lagunaria. In: A.E. Orchard, Flora of Australia. 49: 118-119. AGPS Press, Canberra.

Green, P.S. 1994b. Norfolk Island \& Lord Howe Island. In: A.E. Orchard, Flora of Australia. 49: 1-26. AGPS Press, Canberra.

Greuter, W., J. McNeill, F.R. Barrie, H.M. Burdet, V. Demoulin, T.S. Filgueiras, D. Nicolson, P.C. Silva, J.E. Skog, P. Trehane, J.N. Turland \& P.M. Hawksworth. 2000. International code of botanical nomenclature (St Louis Code) adopted by the sixteenth International Botanical Congress, St Louis, Missouri, July-August 1999. Koeltz, Konigstein. (Regnum Vegetabile 138.)

Pfeil, B.E., C.L. Brubaker, L.A. Craven \& M.D. Crisp. 2002. Phylogeny of Hibiscus and the tribe Hibisceae (Malvaceae) using chloroplast DNA sequences of ndhF and the rpl16 intron. Syst. Bot. 27: 333-350.

Pfeil, B.E., C.L. Brubaker, L.A. Craven \& M.D. Crisp. 2004. Paralogy and orthology in the Malvaceae rpb2 gene family: investigation of gene duplication in Hibiscus. Molec. Biol. Evol. 21: $1428-1437$.

Reichenbach, H.T.L. 1828. Lagunaria. In: H.T.L. Reichenbach, Conspectus Regni Vegetabilis 1: 202. Carolum Cnobloch, Leipzig.

Sims, J. 1804. Lagunaea patersonia. Bot. Mag. 20: t. 769.

Sweet, R. 1839. Lagunaria lilacinus. Hort. Brit., ed. 3: 77.

Vogel, S. 2000. The floral nectaries of Malvaceae sensu lato - a conspectus. Kurtziana 28: 155171. 